\title{
Evaluation of Skin Prick Test Results in Textile Workers
}

\section{Suat Konuk*, Tuncer Tuğ}

Abant Izzet Baysal University, Faculty of Medicine, Pulmonology Department, Bolu, Turkey

*Corresponding Author: Suat Konuk, Abant Izzet Baysal University, Faculty of Medicine, Pulmonology Department, Bolu, Turkey, Tel: 90507341 0126; E-mail: suatkonukk@windowslive.com

Received: 18 February 2018; Accepted: 27 February 2018; Published: 01 March 2018

\begin{abstract}
Objective: Factors such as genetic susceptibility, climate, humidity, vegetation, altitude affect the development of allergy. Exposure to these factors may create allergic related problems in an individual. Based on this we are planning to determine the allergic sensitivity of textile workers in Düzce province of Turkey.
\end{abstract}

Methods: The files of 1142 patients with respiratory allergic disease complaints referred to the pulmonology department in Düzce between April 2014 and January 2017 were retrospectively reviewed. Among those referred to pulmonology examination, there were factory workers coming for periodical controls on the grounds of the agreement protocol with occupational health and safety center and workplace medicine center. This study was planned taking into consideration the textile workers who came for the periodical examination or spontaneously applied. After the restrospective examination of 1142 patient files with respiratory allergic disease complaints, 117 were textile workers among these patients were separately evaluated retrospectively. Skin prick test results were evaluated according to age and sex in textile workers.

Results: Of the 117 patients who worked as textile workers, 75 (64.1\%) were males and $42(35.9 \%)$ were females. The most frequent reaction was found against $D$. farinea with 19 patients $(16.2 \%)$. Other common reactions were found in 15 patients (12.8\%) against $D$. pteronyssinus, 6 patients $(5.1 \%)$ against grass, 5 patients $(4.3 \%)$ against grains and 5 patients (4.3\%) against grass mixes. Reactions were most frequently detected in the 20-29 age group.

Conclusion: Textile workers should be careful especially against house dust mites.

Keywords: Allergy; Textile Worker Allergy; Skin Prick Test 


\section{Introduction}

Atopy is defined as the ability to produce $\operatorname{IgE}$ against allergens in genetically predisposed individuals. Nearly half of the patients with allergic disease develop complaints and are mostly associated with respiratory tract $[1,2]$. Skin prick test (SPT), one of the allergy tests, is a fast, safe, inexpensive and widely used method for the detection of IgEassociated allergies [3]. Due to the wide variety of environmental factors involved in allergies, difficulties are encountered in the diagnosis and treatment of the specific agents [4]. In allergic diseases, regional and geographical differences such as climate, vegetation, humidity, and altitude and seasonal variability are important [5]. Skin prick test is a safe method, although systemic reactions has been reported, no death has been observed [6].

The frequency of allergic diseases is increasing in the general population [4]. Allergic disease is an immunological reaction that occurs in individuals with genetic predisposition, after contact with these allergens, which develops a susceptibility to certain allergens. The most basic step in preventing allergic reactions is to know allergens that one is susceptible and to avoid contact as much as possible [7,8]. This study was undertaken in order to identify and protect the major allergies of patients with allergy complaints from textile workers. This study was conducted to determine the major allergies of the patients who were textile workers and who applied with allergy complaint and to contribute to the protection against said allergens.

\section{Methods}

The files of 1142 patients with respiratory allergic disease complaints referred to the pulmonology department in Düzce between April 2014 and January 2017 were retrospectively reviewed and according to profession 117 textile workers were assessed. People aged 18-65 years were included. Allergen extracts were applied epi-cutane with single prick test applicators. The evaluation was done after 15 minutes of waiting. Histamine hydrochloride was used as a positive control and isotonic as a negative control. The validity criterion of the test was accepted as positive control $>3 \mathrm{~mm}$ and negative control $<3 \mathrm{~mm}$. The skin reaction to the allergen where the induration diameter was observed to be $3 \mathrm{~mm}$ or more was accepted as a positive response [9]. The study was conducted according to the medication and special circumstances that would disrupt the skin tests. Those who were pregnant and those who had active skin diseases have been excluded. For the prick test, 30 common allergen extracts and negative and positive control extracts were used. House dust mites (D. farinea, D. pteronyssinus), grass pollen mixture (Dactylis gomerata, Festuca pratensis, Lolium perenne, Phleum pretense, Poa pseudobulbosa), tree pollen mixture (Betulaceae, Poplar, Hazelnut, Oak, Elm, Ash, Alder, Willow, Beech, Maple, Juniper, Elder-berry, Pine), weed pollen mixture (Artemisia absinthium, Chenopodium, Dikçam grass), cockroach, Aspergillus fumigatus, and grain allergen mixture (oats, barley, wheat, rye), egg whites, egg yolk allergens were used.

SPSS 15.0 Windows package program was used for statistical analysis. The independent-samples $t$ test was used for the variables of mean age. The $\chi 2$ test was used to analyze the gender variables, and the difference was considered significant when $\mathrm{p}<0.05$. Statistical analysis was performed using SPSS (SPSS for Windows, Version 15.0, SPSS Inc, USA) package program. Variables belonging to qualitative data are given as numbers and percentages, quantitative variables are given as medians (min-max). In the comparison of the group with single allergen 
sensitization and the group with multiple allergen sensitization; Chi-square test for categorical variables and MannWhitney $\mathrm{U}$ test for numerical variables was used. Values of $\mathrm{P}<0.05$ were considered statistically significant.

\section{Results}

Of the 117 patients included in the study, $75(64.1 \%)$ were male and $42(35.9 \%)$ were female. The mean age of the women was $35.7 \pm 12.9$, and that of the males was $34.7 \pm 13.0$. In 50 of the test subjects (42.7\%) the skin prick test was positive. Table 1 shows the allergen distribution and percentages seen in males and females. In our study, the reactions to $D$. farinea and $D$. pteronyssinus, which are the most common mites, were detected in the results of the prick test of the patients who complained of allergy complaints.

In Table 1, p value was found to be greater than 0.05 for allergen positivity distribution by sex. That is, no significant difference was found between allergen distribution according to sex.

\begin{tabular}{|l|l|l|l|l|l|}
\hline \multirow{2}{*}{ Type } & \multicolumn{2}{|l|}{ Male (n=75) } & \multicolumn{2}{l|}{ Female (n=42) } & \multirow{2}{*}{$\mathrm{p}$} \\
\cline { 2 - 5 } & $\mathrm{n}$ & $\%$ & $\mathrm{n}$ & $\%$ & \\
\hline Any allergy & 31 & 41.3 & 19 & 45.2 & 0.342 \\
\hline D. farinea & 13 & 17.3 & 6 & 14.3 & 0.435 \\
\hline D. pteronyssinus & 10 & 13.3 & 5 & 11.9 & 0.876 \\
\hline Grass & 4 & 5.3 & 2 & 4.8 & 0.132 \\
\hline Grain & 3 & 4.0 & 2 & 4.7 & 0.564 \\
\hline Weed & 2 & 2.6 & 3 & 7.1 & 0.341 \\
\hline
\end{tabular}

Table 1: Comparison of allergy reactions in terms of sex

All patients undergoing testing were ranked according to their age. Allergic reactions were most frequently detected in the 20-29 age group (Table 2).

\begin{tabular}{|c|c|c|c|}
\hline \multirow{2}{*}{ Age (Years) } & \multirow{2}{*}{ Total number of tests (n) } & \multicolumn{2}{|c|}{ Positive } \\
\cline { 3 - 4 } & & $\mathrm{n}$ & $\%$ \\
\hline $10-19$ & 19 & 7 & 36.8 \\
\hline $20-29$ & 39 & 23 & 58.9 \\
\hline $30-39$ & 23 & 9 & 39.1 \\
\hline
\end{tabular}




\begin{tabular}{|c|c|c|c|}
\hline $40-49$ & 14 & 5 & 35.7 \\
\hline $50-59$ & 12 & 4 & 33.3 \\
\hline$\geq 60$ & 10 & 2 & 20.0 \\
\hline
\end{tabular}

Table 2: Evaluation of skin test results by age distribution

\section{Discussion}

Atopy was defined by Coca and Cooke in 1923 as a predisposition for the development of allergic asthma, allergic rhinitis, allergic conjunctivitis and atopic dermatitis [10]. Following allergen exposure, sensitization develops in 10$20 \%$ of individuals in the general population and a specific immune response is given associated with IgE production. House dust mites are known to be more immunogenic [11]. Allergic diseases are the result of mutual interaction of genetic and environmental factors. Environmental factors include nutrition, domestic and external respiratory allergens, cigarette smoke, infections, and air pollution [12]. A 10-fold increase in the incidence of atopy in developed countries over the past 20 years indicates that environmental factors are responsible for allergy development $[12,13]$. The age of the patient is a factor affecting the results of the prick test. Allergy susceptibility throughout childhood increases with age, forming a plateau in adult age. Sensitivity generally decreases gradually after 50 or 60 years of age, as well as the results of allergy tests performed at these ages [14]. Many studies in our country have reported allergic reactions at different rates in patients with atopic complaints. Some of those; Çiçek et al. [15] 29.3\%, Ceylan et al. [16] 35\%, Karabulut et al. [17] 56.4\% and Öztürk et al. [18] 56.7\% reported various allergy positivity rates. In our study of textile workers, we found at least one allergy positivity in $42.7 \%$ of the results of prick test. The probable cause of this change in rates may be due to the differentiation of allergens in the area or the duration of allergic exposure or the allergic severity of the patients referred to the doctor. Again, the main reason in our study may be the work environment and allergen exposure at work. When we examine the results of the tests, house dust mites and fungi were detected in more mild and humid regions. Sensitivity to house dust was found more frequently in Istanbul [16], Samsun [19] and Osmaniye [1] regions in our country. Çiçek et al. [15] in Elazı ğ detected susceptibility to house dust by $18.1 \%$ and grass pollen by $13.8 \%$. Yalçın et al. [5] In Antalya showed $51.9 \%$ were sensitive to house mites and $42.3 \%$ were sensitive to pollen mixtures. We had D. farinea in 37 patients $(16.1 \%)$, D. pteronyssinus in 29 patients $(12.45 \%)$, grass in 11 patients $(4.7 \%)$, grain in 9 patients $(3.9 \%)$ and weed mixture susceptibility in 9 patients $(3.9 \%)$. We are very close to the sea level and sensitivity to the house mites comes to foreground in Antalya [5]. In another study conducted in Düzce, sensitivity to house mites also comes to the fore [18]. Our work provides information on the consequences of allergen sensitization in textile workers in Düzce, thus revealing what measures should be taken against those working in this field. It is important that the allergy test to be done in the professional groups is an example of their work and that they can lead such studies. It is important that we have an example of the allergy test study that will be done in the profession groups and that we can work with such studies. The fact it is and exemplary allergy test study in specific professional group and that may pioneer similar studies makes our work critical. 


\section{Acknowledgment}

None

\section{Conflict of Interest}

The author declare that he has no conflict of interest

\section{References}

1. Cockcroft DW. Allergens. In: Barnes P, Drazen J, Rennard S, Thomson N (eds). Asthma and COPD: Basic Mechanisms and Clinical Management. London: Academic Press, 2002: 384-393.

2. Crockcroft DW, Murdock KY, Berscheid BA. Relationship between atopy and bronchial responsiveness to histamine in a random population. Annals of allergy 53 (1984): 26-29.

3. Demoly P, Piette V, Bousquet J. In vivo methods for study of allergy: skin tests, techniques and interpretation. In: Adkinson NF, Yunginger JW, Busse WW, Bochner BS, Holgate ST, Simons FER (eds). Allergy, Principles and Practice (6th ed.). New York: Mosby, 2003: 631-655.

4. Baldacci S, Modena P, Carrozzi L, et al. Skin prick test reactivity to common aeroallergens in relation to total IgE, respiratory symptoms, and smoking in a general population sample of northern Italy. Allergy 51 (1996): 149-156.

5. Ayvaz A, Baki A, Doğan C. Trabzon Atmosferindeki Aeroallerjenlerin Mevsimsel Dağılımı. Astım Allerji İmmünoloji 6 (2008): 11-16.

6. Mungan D. Allerji deri testleri. In. Allerjik hastalıklar. Ankara: Antıp A.Ş. Yayınları, 2004: 88-98

7. Kundig TM, Klimek L, Schendzielorz P, Renner WA, Senti G, Bachmann MF. Is The Allergen Really Needed in Allergy Immunotherapy? Curr Treat Options Allergy 2 (2015): 72-82.

8. Calderon MA, Linneberg A, Kleine-Tebbe J, et al. Respiratory allergy caused by house dust mites: What do we really know? J Allergy Clin Immunol 136 (2015): 38-48.

9. Polosa R, Al-Delaimy WK, Russo C, Piccillo G, Sarva M. Greater risk of incident asthma cases in adults with allergic rhinitis and effect of allergen immunotherapy: a retrospective cohort study. Respiratory research 6 (2005): 153.

10. Braun-Falco O, Plewing G, Wolff HH, Burgdorf WHC. Dermatology. Berlin: Springer-Verlag, 2000.

11. Kunt Uzaslan E, Gürdal Yüksel E, Özyardımcı N. Evaluation of the Prick Test, Intradermal Test and RAST Results of the Atopic Asthmatic Patients Followed-up in Asthma Out-patients Clinic. Van Medicine Journal 6 (1999): 13-18.

12. Kanchongkittiphon W, Gaffin JM, Phipatanakul W. The indoor environment and inner-city childhood asthma. Asian Pac J Allergy Immunol 32 (2014): 103-110.

13. Nicolaou N, Siddique N, Custovic A. Allergic disease in urban and rural populations: increasing prevalence with increasing urbanization. Allergy 60 (2005): 1357-1360. 
14. Song WJ, Lee SM, Kim MH et al. Histamine and allergen skin reactivity in the elderly population: results from the Korean Longitudinal Study on Health and Aging. Ann Allergy Asthma Immunol 107 (2011): 344352.

15. Cicek D, Kandi B, Bakar S, Ucak H. Elazı̆̆ Yöresinde Allerjik Astma, Allerjik Rinit, Allerjik Konjunktivit, Kronik Ürtiker ve Atopik Dermatitli Olgularda Prick Test Sonuçlarının Değerlendirilmesi. Fırat Üniversitesi Sağlık Bilimleri Tıp Dergisi 22 (2008): 193-196.

16. Küçükosmanoğlu E, Tanıdır C, Demir F et al. İstanbul'da Çocuklarda Solunum Allerjenleri Duyarlılığı. Gaziantep Medical Journal 15 (2009): 10-13.

17. Karabulut H, Karadağ AS, Acar B, Demir M, Babademez MA, Karaşen RM. Ankara Keçiören bölgesinde deri prik testi sonuçlarının meteorolojik ve demograf ik özelliklere göre değerlendirilmesi. KBB-Forum Dergisi 8 (2009): 46-54.

18. Öztürk Ö, Tokmak A, Güçlü E, Yıldızbaş Ş, Gültekin E. Düzce'de alerjik rinitli hastalarda prick testi sonuçları. Düzce Tıp Fakültesi Dergisi 1 (2005): 11-14.

19. Igde FA, Sancak R, Ozturk F. Orta Karadeniz Bölgesindeki Çocuklarda Allerji Deri Testi Sonuçları. 18 (2009): 82-90.

Citation: Suat Konuk, Tuncer Tuğ. Evaluation of Skin Prick Test Results in Textile Workers. Archives of Clinical and Biomedical Research 2 (2018): 036-041. 